\title{
EDUKASI FINTECH BAGI MASYARAKAT DESA BOJONG SEMPU BOGOR
}

\author{
Suharyati $^{1}$, Pahrizal Sofyan ${ }^{2}$ \\ Fakultas Ekonomi dan Bisnis, Universitas Pembangunan Nasional "Veteran” Jakarta, \\ Jl. R.S. Fatmawati No. 1 Pondok Labu - Jakarta Selatan 12450 \\ Email: 1yatididi01@gmail.com dan 2pahrizals@gmail.com
}

\begin{abstract}
ABSTRAK
Era revolusi industri 4.0 merupakan tantangan bagi suatu negara untuk mengubah model bisnis konvensional kedalam sistem berteknologi. Penggunaan teknologi inovatif di bidang keuangan (Financial Technology) menuntut model bisnis konvensional untuk segera berubah kearah moderat. FinTech muncul seiring perubahan gaya hidup masyarakat yang didominasi oleh pengguna teknologi informasi untuk menjadi penghubung antara sektor finansial dengan pengguna atau masyarakat umum. Indonesia merupakan pasar besar bagi FinTech seiring dengan meningkatnya mayoritas pengguna teknologi internet untuk transaksi bisnis. Menurut Indonesia's Fintech Association (IFA), jumlah FinTech di Indonesia hingga November 2016, tercatat lebih dari 135 perusahaan. FinTech merupakan perusahaan yang menyediakan teknologi untuk memfasilitasi layanan keuangan (startup) secara independen di luar lembaga keuangan konvensional. FinTech sangat berpotensi menjadi salah satu solusi untuk mengatasi masalah transaksi keuangan bagi masyarakat yang bertempat tinggal jauh dari pusat kota. Berdasarkan pada fenomena diatas, tim pengabdian pada masyarakat Fakultas Ekonomi UPN Veteran Jakarta, telah melakukan edukasi pengenalan FinTech bagi masyarakat di desa Bojong Sempu, Kecamatan Parung, Kabupaten Bogor, sebagai kepedulian akan pentingnya pengenalan teknologi untuk memfasilitasi layanan keuangan (startup) di era industri 4.0 ini. Hasil kuesioner yang diberikan kepada peserta menunjukkan bahwa pemahaman peserta setelah diberikan edukasi Fintech mencapai $70 \%$.
\end{abstract}

Kata kunci : FinTech, layanan keuangan, startup, perbankan.

\section{PENDAHULUAN}

Peluang dan tantangan dunia usaha di era globalisasi serta era revolusi industri ke 4, sangat besar, seiring dengan meningkatnya kemajuan teknologi di berbagai bidang. Di Indonesia, saat ini jumlah penduduk mencapai 262 juta orang dan sekitar 143 juta orang telah terhubung jaringan internet sepanjang 2017, menurut Asosiasi Penyelenggara Jasa Internet Indonesia (APJII). Mayoritas pengguna internet sebanyak 72,41 persen masih dari kalangan masyarakat urban yang pemanfaatannya bukan hanya untuk berkomunikasi tetapi juga membeli barang, memesan

transportasi, hingga berbisnis dan berkarya. Pengguna internet di Tanah Air sebanyak 49,52 persen berada pada usia muda, berkisar 19 hingga 34 tahun, (Kompas.com,2018)

Menurut Bank Indonesia, 64\% penduduk Indonesia adalah unbanked, dimana mereka lebih suka dengan layanan keuangan yang lebih fleksibel. Saat ini masyarakat sangat tergantung terhadap penggunaan teknologi, hal ini yang menjadi pemicu berkembangnya teknologi bidang keuangan (Fintech) untuk mendukung berbagai layanan keuangan di Indonesia. Penggunaan teknologi inovatif di bidang keuangan merupakan tantangan bagi banyak model bisnis tradisional. Saat ini diperkirakan terdapat lebih dari 140 perusahaan start-up dan diprediksi terus bertambah sejalan dengan masih besarnya potensi pasar yang belum terjamah dengan layanan yang ditawarkan semakin beragam, mulai dari pembayaran, pembiayaan/pinjaman, investasi di pasar modal hingga asuransi dikemas lebih menarik dengan sentuhan Fintech, (Budi Raharjo,2018). 
Financial Technology (Fintech) merupakan suatu terobosan dalam teknologi yang menjadi penghubung antara sektor finansial dengan pengguna atau masyarakat umum. Fintech sangat berpotensi menjadi salah satu solusi untuk mengatasi masalah yang sedang ada di masyarakat khususnya masyarakat yang bertempat tinggal jauh dari pusat kota maupun bagi masyarakat yang tergolong unbanked. Fintech merupakan singkatan dari kata Financial Technology, yang dapat diartikan dalam bahasa Indonesia menjadi teknologi keuangan. Secara sederhana, Fintech dapat diartikan sebagai pemanfaatan perkembangan teknologi informasi untuk meningkatkan layanan di industri keuangan. Definisi lainnya adalah variasi model bisnis dan perkembangan teknologi yang memiliki potensi untuk meningkatkan industri layanan keuangan. Kebutuhan masyarakat, mendorong para pelaku jasa keuangan untuk terus melakukan inovasi dan transformasi dari transaksi secara tradisional ke dalam bentuk digital, dengan proses yang lebih singkat, mudah, dan terjangkau dengan adanya platform digital. (https://konsumen.ojk.go.id/)

Otoritas Jasa Keuangan (OJK) mengeluarkan Peraturan OJK Nomor 13/POJK.02/2018 tentang Inovasi Keuangan Digital di Sektor Jasa Keuangan sebagai ketentuan yang memayungi pengawasan dan pengaturan industri Financial Technology (Fintech), dimana sebelumnya telah mengeluarkan peraturan OJK Nomor 77/POJK.01/2016 tentang Layanan Pinjam Meminjam Uang Berbasis Teknologi Informasi. Menurut Ketua Dewan Komisioner OJK, Wimboh Santoso, Peraturan ini dikeluarkan OJK mengingat cepatnya kemajuan teknologi di industri keuangan digital yang tidak dapat diabaikan dan perlu dikelola agar dapat memberikan manfaat sebesar-besarnya untuk kepentingan masyarakat. Inovasi keuangan digital perlu diarahkan agar menghasilkan inovasi keuangan digital yang bertanggung jawab, aman, mengedepankan perlindungan konsumen dan memiliki risiko yang terkelola dengan baik. Peraturan ini juga dikeluarkan sebagai upaya mendukung pelayanan jasa keuangan yang inovatif, cepat, murah, mudah, dan luas serta untuk meningkatkan inklusi keuangan, investasi, pembiayaan serta layanan jasa keuangan lainnya. (detik.com,2018)

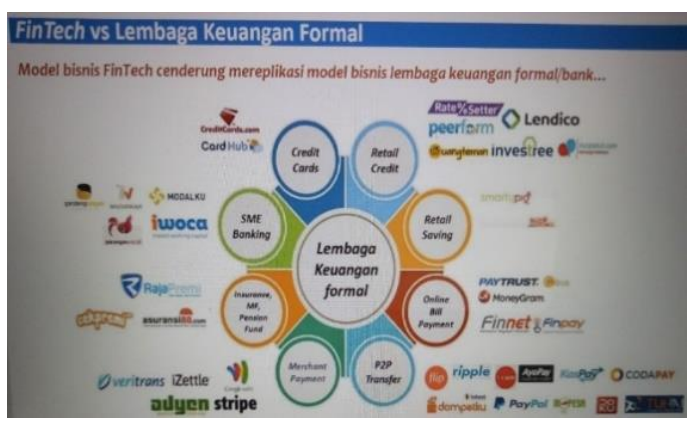

(a)

Sumber: Bank Indonesia, 2017

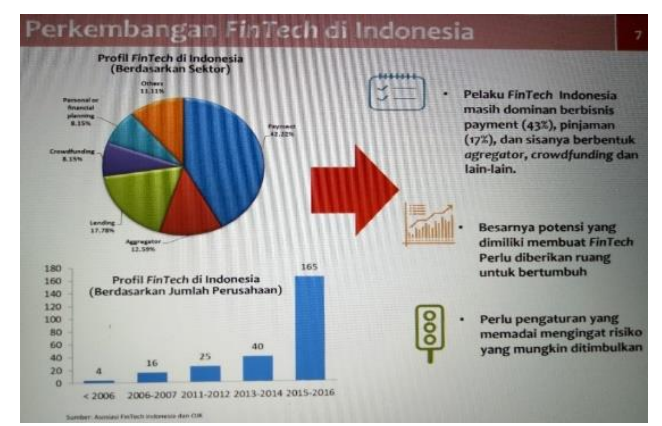

(b)

Gambar 1. (a) Fintech vs Lembaga Keuangan Formal (b) Perkembanhan Fintech di Indonesia

Mengingat pentingnya pengenalan teknologi dalam bidang layanan keuangan ini bagi masyarakat, khususnya yang jauh dari jangkauan perbankan dan lembaga keuangan konvensional dan meningkatnya kebutuhan layanan keuangan bagi masyarakat yang lebih fleksibel, mudah, cepat dan aman, maka perlu adanya sosialisasi atau edukasi bagi masyarakat mengenai Financial Technology (Fintech) ini. 
Salah satu desa di wilayah kecamatan Parung, kabupaten Bogor yaitu desa Bojong Sempu yang memiliki luas $1.60 \mathrm{~km}^{2}$ dengan jumlah penduduk 9.829 jiwa, dimana mata pencaharian terdiri dari Pertanian sebanyak 55 unit usaha, Peternakan sebanyak 20 unit usaha, Perikanan sebanyak 165 unit usaha, Perdagangan sebanyak 867 unit usaha, Industri dan Pengolahan sebanyak 257 unit usaha, selebihnya adalah pegawai Pemerintah maupun swasta. Kondisi desa Bojong Sempu berada jauh dari pusat keramaian sehingga untuk melakukan transaksi dengan lembaga perbankan dan lembaga keuangan formal mengalami kendala. Dengan kemajuan teknologi dibidang keuangan, berada jauh dari perkotaan seharusnya bukan merupakan hambatan lagi untuk melakukan transaksi keuangan. Terobosan dari Fintech mampu mengatasi permasalahan transaksi keuangan dengan lebih mudah dan cepat.

Pengenalan akan teknologi baru dibidang keuangan ini harus disosialisakan kepada masyarakat dan sudah merupakan tanggungjawab kita bersama, khususnya perguruan tinggi. Berdasarkan hal tersebut, maka Fakultas Ekonomi dan Bisnis UPN Veteran Jakarta, berupaya untuk membantu masyarakat di desa Bojong Sempu untuk melakukan edukasi mengenai Financial Technology dengan tujuan memberikan pemahaman dan pelatihan penggunaan aplikasi keuangan dengan mempergunakan smartphone.

Kegiatan edukasi Fintech bagi masyarakat di desa Bojong Sempu ini dilakukan dengan bermitra pada kelompok masyarakat yang terdiri dari kelompok PKK, kelompok Pengajian, kelompok Karang Taruna. Pemahaman akan penggunaan Fintech ini mempunyai kontribusi dalam percepatan laju ekonomi daerah yang berdampak pada peningkatan ekonomi Indonesia pada umumnya.

Berdasarkan pada fenomena diatas maka diperlukan kegiatan pengabdian kepada masyarakat berupa edukasi "Financial Technology bagi masyarakat desa Bojong Sempu, Bogor", untuk menambah kreativitas dan inovasi bagi mitra dalam menggunakan teknologi keuangan untuk memenuhi kebutuhannya.

Berdasarkan latar belakang yang meliputi kondisi obyektif, profil wilayah dan serta peluang yang ada bagi masyarakat khususnya desa Bojong Sempu, Bogor maka dibuat perumusan masalah yaitu pentingnya edukasi internet marketing bagi pengrajin Baduy melalui edukasi dan pembekalan Financial Technology bagi masyarakat desa Bojong Sempu sebagai sarana untuk memenuhi layanan keuangan mereka.

\section{TINJAUAN PUSTAKA}

a. Pengertian Inovasi Disruptif (Disruptive Innovation) dan Financial Technology (Fintech)

\section{Inovasi Disruptif (Disruptive Innovation).}

Adalah sebuah inovasi yang berhasil mentransformasi suatu sistem atau pasar yang eksisting, dengan memperkenalkan kepraktisan, kemudahan akses, kenyamanan, dan biaya yang ekonomis, dikenal sebagai Inovasi Disruptif (Disruptive Innovation). Inovasi Disruptif ini biasanya mengambil segmen pasar tertentu yang kurang diminati atau dianggap kurang penting bagi penguasa pasar, namun inovasinya bersifat breakthrough dan mampu meredefinisi sistem atau pasar yang eksisting. Fenomena Inovasi Disruptif juga terjadi di Industri Jasa Keuangan yang telah mendisrupsi landscape Industri Jasa Keuangan secara global. Mulai dari struktur industrinya, teknologi intermediasinya, hingga model pemasarannya kepada konsumen. Keseluruhan perubahan ini mendorong munculnya fenomena baru yang disebut Financial Technology (Fintech). https://www.duniafintech.com 


\section{Financial Technology (Fintech)}

Fintech merupakan singkatan dari kata Financial Technology, yang dapat diartikan dalam bahasa Indonesia menjadi teknologi keuangan. Secara sederhana, Fintech dapat diartikan sebagai pemanfaatan perkembangan teknologi informasi untuk meningkatkan layanan di industri keuangan. Definisi lainnya adalah variasi model bisnis dan perkembangan teknologi yang memiliki potensi untuk meningkatkan industri layanan keuangan.

Kebutuhan masyarakat ini mendorong para pelaku jasa keuangan untuk terus melakukan inovasi dan transformasi dari transaksi secara tradisional ke dalam bentuk digital. Kegiatan dalam sektor jasa keuangan, seperti mendatangi bank untuk melakukan transaksi, bertemu dengan agen penjual langsung untuk mendaftarkan diri sebagai konsumen asuransi, atau mendatangi perusahaan sekuritas bagi masyarakat yang ingin berinvestasi, diharapkan dapat digantikan dengan proses yang lebih singkat, mudah, dan terjangkau dengan adanya platform digital. Pelaku usaha jasa keuangan (PUJK) juga dituntut untuk meningkatkan standar dan inovasi untuk menarik serta memenuhi kebutuhan masyarakat yang semakin modern. Upaya yang dilakukan adalah dengan mengembangkan produk inovatif dan menguatkan sistem teknologi dalam bisnis yang dilakukan oleh pelaku jasa keuangan. Dengan demikian, pelaku jasa keuangan dapat bersaing pula dengan perusahaan-perusahaan Fintech yang berkembang di Indonesia bahkan regional dan internasional. (https://konsumen.ojk.go.id/)

\section{b. Peran Teknologi Finansial Serta Regulasinya di Indonesia}

Simon Iqbal Fahlevi, 2016, Sektor finansial memiliki peran yang penting untuk mendukung kekuatan perekonomian suatu Negara. Dengan perkembangan teknologi yang semakin maju, sektor finansial juga turut mengalami perkembangan ke arah yang lebih modern dan praktis. Bisnis teknologi finansial atau dalam bahasa Inggris disebut financial technology (fintech) kini sedang naik daun di Indonesia. Ada banyak hal yang bisa dikategorikan ke dalam bidang fintech, diantaranya adalah proses pembayaran, proses pembukuan, jual beli saham, peminjaman uang serta masih banyak lagi.

Regulasi mengenai teknologi keuangan alias financial technology (fintech) sendiri sedang di kaji oleh Otoritas Jasa Keuangan (OJK). OJK memastikan akan mengawasi bisnis yang dijalani oleh Financial Technology (fintech) dengan sejumlah aturan yang ketat dimana akan dikeluarkan pada akhir tahun 2016. Satu hal yang nantinya akan dibuat aturan yang jelas adalah terkait penentuan batas modal minimal industri fintech. Salah satu alasan dibuatnya aturan tersebut adalah untuk perlindungan konsumen.

Startup fintech tentunya tidak akan banyak bermunculan bila tidak memiliki peran yang besar. Banyak hal yang membuat perkembangan fintech mampu mempengaruhi gaya hidup masyarakat dunia. Alasan-alasan tersebut membuat bidang fintech terus tumbuh menjadi sebuah kebutuhan baru bagi masyarakat.

Davis, K., Maddock, R., \& Foo, M. (2017), The innovative use of technology in finance is posing challenges to many traditional business models. At the same time it is challenging regulators. The key issue they face is how to balance the desire to encourage new businesses so as to intensify competition and provide better customer services in the sector, while protecting the system and consumers from excessively risky behaviour and potential disruption. For Indonesia the opportunity is very large given the uneven availability of finance and low levels of financial inclusion.

Hal ini dapat diartikan bahwa penggunaan teknologi inovatif di bidang keuangan merupakan tantangan bagi banyak model bisnis tradisional. Pada saat yang sama itu menantang regulator. 
Masalah utama yang mereka hadapi adalah bagaimana menyeimbangkan keinginan untuk mendorong bisnis baru untuk mengintensifkan persaingan dan memberikan layanan pelanggan yang lebih baik di sektor ini, sementara melindungi sistem dan konsumen dari perilaku yang terlalu berisiko dan gangguan potensial. Bagi Indonesia peluang sangat besar mengingat ketersediaan keuangan yang tidak merata dan rendahnya tingkat inklusi keuangan.

Timbulnya Fintech di Indonesia, dimana masyarakat tidak dapat terlayani oleh industri keuangan tradisional oleh karena perbankan terikat pada aturan yang ketat dan keterbatasan industri perbankan dalam melayani masyarakat di daerah tertentu. Dengan demikian masyarakat mencari alternatif pendanaan selain jasa industri keuangan tradisional, yaitu alternatif pembiayaan yang lebih demokratis dan transparan; Biaya layanan keuangan yang efisien dan menjangkau masyarakat luas.

\section{Peran Fintech di Indonesia :}

1) Mendorong pemerataan tingkat kesejahteraan penduduk

2) Membantu pemenuhan kebutuhan pembiayaan dalam negeri yang masih sangat besar

3) Mendorong distribusi pembiayaan Nasional masih belum merata di 17.000 pulau

4) Meningkatkan Inklusi keuangan nasional

5) Mendorong kemampuan ekspor UMKM yang saat ini masih rendah

\section{c. Katagori dan Jenis-Jenis Startup Fintech}

Katagori Fintech terdiri dari Deposits, Lending, Capital Raising; Market Provisioning; Payment, Clearing\&Settlement; Investment\&Risk Management.

Iqbal Kurniawan, https://id.techinasia.com/startup-fintech-lending-indonesia-2018, dalam tulisannya memuat, di Indonesia telah ada beberapa jenis startup yang bergerak di bidang fintech lending, antara lain:

1) Startup P2P lending, startup jenis ini antara lain terdiri dari Modalku, Investree, Amartha, KoinWorks, hingga Crowdo. Semua startup tersebut hanya bertindak sebagai marketplace yang menghubungkan para peminjam dengan para pemberi pinjaman, serta hanya mengambil komisi dari setiap transaksi yang terjadi di platform masing-masing. Keberadaan startup P2P lending saat ini telah dilegalkan oleh OJK, lewat POJK No. 77 Tahun 2016. Dalam aturan tersebut, OJK membatasi nilai maksimal pinjaman yang bisa disalurkan oleh startup P2P lending, yaitu sebesar Rp2 miliar.

2) Startup on balance sheet lending, jenis startup ini memberikan pinjaman secara langsung dari kantong mereka sendiri. Untuk mengurangi risiko, biasanya hanya memberikan pinjaman dengan nominal yang tidak terlalu besar, dan jangka waktu pengembalian yang tidak terlalu panjang. Beberapa startup yang masuk kategori ini adalah UangTeman, Julo, TunaiKita, dan Doctor Rupiah.

3) Startup penyedia kredit atas transaksi online, menyediakan pinjaman untuk pembelian barang secara online, biasanya bekerja sama dengan beberapa e-commerce, dan memungkinkan untuk membeli sebuah barang dan membayarnya di kemudian hari secara mencicil adalah Kredivo, Akulaku, dan Cicil,

4) Startup pemberi pinjaman dengan mekanisme gadai, Startup yang bisa memberikan pinjaman dengan menggadaikan barang berharga, seperti emas, kendaraan, hingga barang elektronik. Contoh startup yang menjalankan bisnis ini secara online adalah Pinjam. 


\section{METODOLOGI}

Kegiatan pemberdayaan masyarakat ini, dilakukan dengan memberikan edukasi dan pembekalan Financial Technology bagi masyarakat desa Bojong Sempu kabupaten Bogor. Melalui edukasi ini dapat meningkat pemahaman tentang pemanfaatan teknologi keuangan sebagai sarana pemenuhan kebutuhan akan layanan keuangan berbasis teknologi.

Tabel 1. Prosedur kerja

\begin{tabular}{|c|l|l|}
\hline $\begin{array}{c}\text { TAHAP } \\
\text { KE }\end{array}$ & \multicolumn{1}{|c|}{ KEGIATAN } & \multicolumn{1}{|c|}{ INDIKATOR } \\
\hline 1 & $\begin{array}{l}\text { Edukasi mengenai Financial Technology } \\
\text { Dalam kegiatan ini peserta mendengarkan } \\
\text { ceramah dan melakukan diskusi/tanya jawab }\end{array}$ & $\begin{array}{l}\text { Dilakukan test dengan memberikan } \\
\text { kuesioner untuk menilai } \\
\text { pemahaman materi }>70 \%\end{array}$ \\
\hline 2 & $\begin{array}{l}\text { Mempapaian } \\
\text { keuangan melalui smartphone } \\
\text { Dalam Pembekalan ini peserta langsung ikut } \\
\text { untuk mempraktekkan }\end{array}$ & $\begin{array}{l}\text { Dapat mempraktekkan mengunduh dan } \\
\text { membuka aplikasi melalui smartphone } \\
\%\end{array}$ \\
\hline
\end{tabular}

Metode Pendekatan

Edukasi dan pembekalan dilakukan dengan cara memberikan edukasi mengenai Financial Technology dengan metode ceramah dan membagikan materi paparan. Disamping itu diberikan pembekalan berupa cara menggunakan berbagai aplikasi keuangan melalui smartphone

Kegiatan pengabdian masyarakat berupa edukasi Fintech ditujukan bagi masyarakat desa Bojong Sempu kabupaten Bogor yang dilakukan dengan tahapan : (1) Tahap awal melakukan perijinan untuk melaksanakan program Pengabdian kepada masyarakat kepada mitra dengan cara melakukan studi lapangan untuk mempelajari masalah yang menjadi permasalahan prioritas mitra, mempelajari budaya setempat terhadap permasalahan masyarakat yang ada, melakukan kerjasama dengan Kepala desa Bojong Sempu untuk melaksanakan program pengabdian kepada masyarakat sebagai solusi terhadap permasalahan prioritas mitra. (2) Tahap pelaksanaan dengan cara melakukan pembelajaran kepada masyarakat tentang Fintech, melakukan pelatihan kepada masyarakat untuk memanfaatkan fasilitas Fintech melalui media smart phone. (3) Tahap akhir melakukan pelaporan hasil pelaksanaan program pengabdian kepada masyarakat pada mitra dengan cara memantau keberlanjutan pelaksanaan program pengabdian kepada masyarakat pada mitra, mempublikasikan laporan pelaksanaan program pengabdian kepada masyarakat sebagai bahan informasi.

Partisipasi Mitra Selama pelaksanaan kegiatan, Mitra berpartisipasi dalam pelaksanaan program pengabdian kepada masyarakat ini dari tahap awal hingga tahap akhir yaitu : (1) Pada tahap awal perijinan pelaksanaan program pengabdian kepada masyarakat ini mitra berpartisipasi dalam memberikan informasi tentang permasalahan yang dihadapi mitra, memberikan perijinan kepada Fakultas Ekonomi dan Bisnis Universitas Pembangunan Nasional Veteran Jakarta untuk melakukan studi lapangan pada wilayah mitra, memberikan perijinan program edukasi dan pembekalan Fintech. (2) Pada tahap pelaksanaan, mitra berpartisipasi dalam menyediakan sarana prasarana yang diperlukan (3) Pada tahap akhir pelaksanaan pengabdian kepada masyarakat, mitra bersedia untuk dilakukan monitoring keberlanjutan pelaksanaan program ini. 


\section{HASIL PENGABDIAN KEPADA MASYARAKAT}

Hasil pengabdian kepada masyarakat berupa edukasi Fintech bagi masyarakat di desa Bojong Sempu, Kecamatan Parung, Kabupaten Bogor sebagai berikut :

\subsection{Diskripsi Data Peserta Edukasi}

Tabel 2. Jenis Kelamin

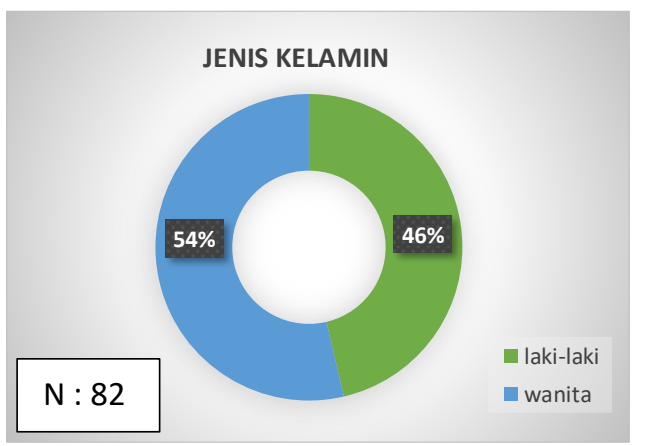

Tabel 4. Durasi penggunaan Gadget per hari

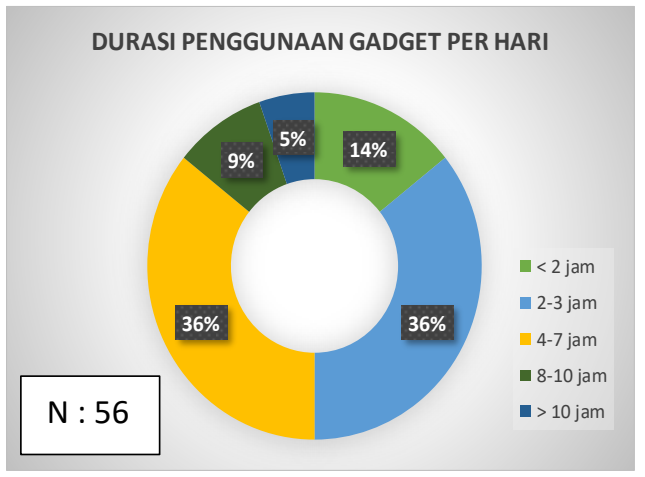

Tabel 3. Usia Peserta

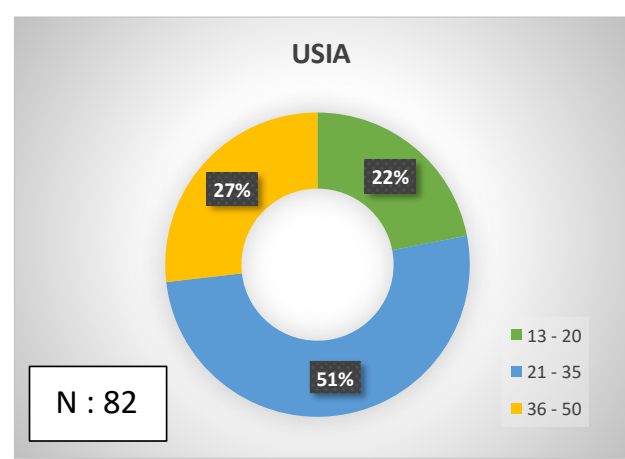

Tabel 5. Lama Pemakaian Gadget

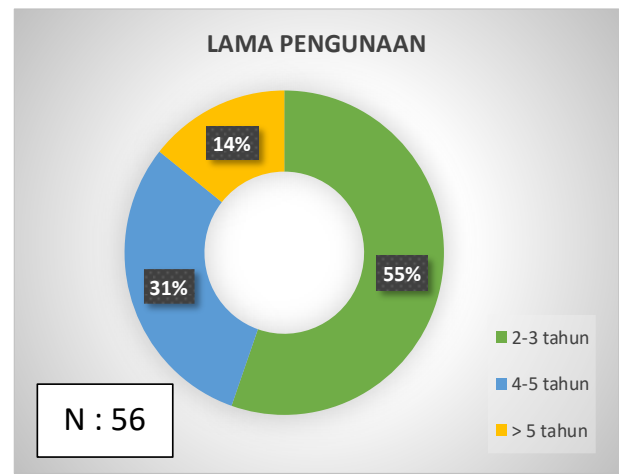

Berdasarkan data yang diperoleh dari peserta edukasi adalah jumlah peserta sebanyak 82 orang yang terdiri dari $54 \%$ wanita dan $46 \%$ pria, dengan usia 13 - 20 tahun sebanyak $22 \%$, usia 21 35 tahun sebanyak $51 \%$ dan usia 36-50 tahun sebanyak $27 \%$. Durasi penggunaan gadget dari 56 pengguna, terbanyak yaitu 2-3 jam dan 4-7 jam sehari masing-masing sebesar 36\% sedangkan durasi penggunaan gadget terkecil yaitu $5 \%$ untuk durasi lebih kecil dari 2 jam. Berdasarkan lamanya pemakaian gadget $55 \%$ dengan masa pemakaian 2-3 tahun, $31 \%$ untuk masa pemakaian 4-5 tahun dan lama pemakaian diatas 5 tahun sebesar $14 \%$.

Berdasarkan data yang diperoleh tersebut maka pengguna gadget lebih didominasi wanita dan dari segi usia berkisar : 21 - 35 tahun. Durasi penggunaan gadget terbesar berada di 2-3 jam dan 4-7 jam. Hal ini merupakan potensi bagi pengguna Fintech. Untuk itu sangat diperlukan sosialisasi mengenai Fintech agar lebih memahami berbagai perusahaan starup serta resikoresiko dan manfaat yang didapat dari penggunaan teknologi layanan keuangan ini 


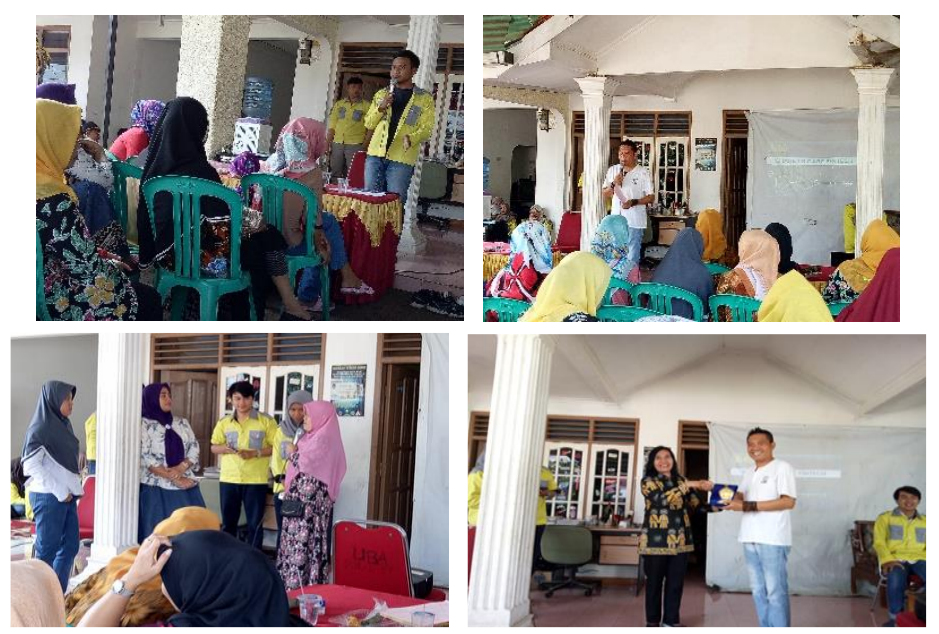

Gambar 2. Foto Kegiatan Edukasi Fintech

\subsection{Diskripsi Hasil Kuesioner}

Berdasarkan hasil kuesioner yang terdiri dari 10 butir pernyataan, seperti pada tabel 4.2.5. dibawah ini dapat diketahui nilai rata -rata pemahaman peserta edukasi tentang Fintech sebagai sarana pemasaran produk mencapai 70,86\% telah melebihi standar pencapaian yaitu sebesar $70 \%$. Nilai tertinggi terdapat pada butir pernyataan satu yaitu pemahaman mengenai fungsi BI dalam menjaga ketertiban lalulintas pembayaran terkait Fintech dan Fintech memudahkan layanan transaksi keuangan. Dengan demikian edukasi mengenai Fintech bagi masyarakat desa Bojong Sempu, Kecamatan Parung, Kabupaten Bogor dinyatakan berhasil.

Tabel 6. Butir Pertanyaan

Sumber : Data diolah

\begin{tabular}{|c|c|c|c|c|}
\hline No. & Butir Pertanyaan & Kode & Penilaian & $\%$ \\
\hline 1 & Pemahaman revolusi 4.0, dibidang layanan keuangan & Q1 & 3,7 & $74 \%$ \\
\hline 2 & Pemahaman mengenai Fintech & Q2 & 3,6 & $72 \%$ \\
\hline 3 & Pemahaman mengenai dasar hukum Fintech & Q3 & 3,1 & $63 \%$ \\
\hline 4 & Pemahaman Keuntungan dengan adanya Fintech & Q4 & 3,4 & $68 \%$ \\
\hline 5 & Pemahaman mengenai dampak dari Fintech & Q5 & 3,2 & $64 \%$ \\
\hline 6 & Pemahaman mengenai Peran Fintech dalam sistem pembayaran & Q6 & 3,6 & $71 \%$ \\
\hline 7 & Pemahaman pentingnya Bank Indonesia membuat peraturan mengenai Fintech & Q7 & 3,7 & $73 \%$ \\
\hline 8 & $\begin{array}{l}\text { Pemahaman mengenai fungsi BI dalam menjaga ketertiban lalulintas } \\
\text { pembayaran terkait Fintech }\end{array}$ & Q8 & 3,8 & $75 \%$ \\
\hline 9 & $\begin{array}{l}\begin{array}{l}\text { Pemahaman Fungsi BI terkait Fintech sebagai Fasilitator, Asesmen, Kordinasi } \\
\text { dan Komunikasi }\end{array} \\
\end{array}$ & Q9 & 3,7 & $74 \%$ \\
\hline \multirow[t]{2}{*}{10} & Pemahaman Fintech memudahkan layanan dalam transaksi keuangan & Q10 & 3,7 & $75 \%$ \\
\hline & Nilai Rata-rata & & 3,5 & $\mathbf{7 0 , 8 6 \%}$ \\
\hline
\end{tabular}

Tabel 7. Frekuensi Jawaban Frequencies

Sumber : Hasil olahan

\begin{tabular}{|c|c|c|c|c|c|c|c|c|c|c|c|}
\hline \multicolumn{12}{|c|}{ Statistics } \\
\hline & & Q1 & Q2 & Q3 & Q4 & Q5 & Q6 & Q7 & Q8 & Q9 & Q10 \\
\hline \multirow[t]{2}{*}{$\bar{N}$} & Valid & 56 & 56 & 56 & 56 & 56 & 56 & 56 & 56 & 56 & 56 \\
\hline & Missing & 0 & 0 & 0 & 0 & 0 & 0 & 0 & 0 & 0 & 0 \\
\hline \multicolumn{2}{|c|}{ Mean } & 3,71 & 3,59 & 3,14 & 3,39 & 3,18 & 3,55 & 3,66 & 3,75 & 3,71 & 3,73 \\
\hline \multicolumn{2}{|c|}{ Median } & 4,00 & 4,00 & 3,00 & 3,00 & 3,00 & 3,00 & 4,00 & 4,00 & 4,00 & 4,00 \\
\hline \multicolumn{2}{|c|}{ Mode } & 4 & 4 & 3 & 3 & 3 & 3 & 4 & 4 & 4 & 4 \\
\hline \multicolumn{2}{|c|}{ Minimum } & 2 & 2 & 2 & 2 & 2 & 2 & 3 & 3 & 2 & 2 \\
\hline \multicolumn{2}{|c|}{ Maximum } & 5 & 5 & 5 & 5 & 5 & 5 & 5 & 5 & 5 & 5 \\
\hline \multicolumn{2}{|c|}{ Sum } & 208 & 201 & 176 & 190 & 178 & 199 & 205 & 210 & 208 & 209 \\
\hline
\end{tabular}




\section{DISKUSI}

Revolusi industri 4.0 telah membawa dampak bagi layanan keuangan, dimana teknologi sudah semakin maju, kebutuhan pelanggan saat ini adalah pelayanan yang cepat dan memuaskan. Penggunaan berbagai aplikasi di smart phone atau gadget sudah menjadi suatu tren dalam pemenuhan kebutuhannya. Perusahaan yang tidak memanfaatkan teknologi dalam pengeloaan perusahaan perusahaannya pasti akan ditinggalkan pelanggan mereka.

Saat ini daerah-daerah sub urban seperti desa Bojong Sempu yang berada di Kecamatan Parung, Kabupaten Bogor, sangat memerlukan sosialisasi atau edukasi mengenai layanan keuangan yang mudah dan fleksibel ini tidak lagi berbelit-belit serta membutuhkan proses lama. Seperti kita ketahui bahwa pengguna internet di Indonesia mencapai 54,68 \% sedangkan diwilayah sub urban mencapai 49,49\% (APJII,2017), dengan demikian berpengaruh pada potensi penggunaan aplikasi layanan keuangan.

Edukasi mengenai Fintech desa Bojong Sempu yang berada di Kecamatan Parung, Kabupaten Bogor, sangat dibutuhkan untuk menambah pengetahuan akan manfaat penggunaan layanan keuangan yang telah menggunakan teknologi untuk mempermudah transaksi keuangan. Jumlah peserta edukasi sebanyak 82 orang dengan usia terbanyak 21-35 sebesar 51\% dan rata -rata telah mampu menggunakan internet.

Selama diberikan edukasi dan pelatihan peserta sangat antusias dan berusaha untuk memahami lebih dalam dan mencoba untuk mengunduh beberapa aplikasi Fintech. Dari hasil edukasi ini, tercapai pemahaman sebesar 70,86\% melebihi standar capaian sebesar $70 \%$. Peserta yang mengunduh aplikasi Fintech terdapat 56 orang (68\%) melebihi standar capaian sebesar $60 \%$.

Sehubungan dengan kebutuhan akan layanan keuangan yang menuntut teknologi kekinian yang dapat menghemat biaya serta waktu maka sudah selayaknya pemerintah setempat, institusi terkait bahkan perguruan tinggi harus memberikan dukungan bagi masyarakat sub urban untuk lebih meningkatkan pemahamannya mengenai Fintech. Keberhasilan masyarakat dalam memanfaatkan layanan keuangan tentunya akan mendorong peningkatan ekonomi masyarakat, ekonomi daerah bahkan ekonomi Indonesia. Untuk itu perlu dilakukan secara rutin edukasi dan pelatihan seperti ini untuk lebih meningkatkan pengetahuan dan pemahaman masyarakat akan layanan keuangan berbasis kekinian.

\section{KESIMPULAN}

Berdasarkan hasil pengabdian kepada masyarakat berupa edukasi Fintech, bagi masyarakat desa Bojong Sempu yang berada di Kecamatan Parung, dapat ditarik kesimpulan pemahaman peserta edukasi mengenai Fintech tercapai sebesar yaitu 70,86\% dan peserta yang berhasil mengunduh applikasi keuangan sebesar $68 \%$. Hal ini memberi arti dimana masyarakat diwilayah sub urban ini antusias untuk memanfaatkan fasilitas layanan keuangan dengan teknologi masa kini.

Fintech merupakan salah satu cara untuk mendorong peningkatan ekonomi masyarakat melalui peningkatan transaksi keuangan. Untuk itu di era revolusi industri 4.0 dimana tehnologi meningkat dengan cepat sudah selayaknya masyarakat di pedesaan dapat pula menggunakan teknologi layanan keuangan ini sebagai tren yang harus diikuti. 


\section{DARTAR PUSTAKA}

Abyan, Muhammad Alvin. (2018). Konsep Penggunaan Financial Technology dalam Membantu Masyarakat Sub Urban di Indonesia dalam Melakukan Transaksi Finansial https://www.researchgate.net/publication/324386435

Bank Indonesia. (2017). Edukasi Perlindungan Konsumen. https://www.bi.go.id/id/edukasi-perlindungan-konsumen/edukasi/produk-dan-jasa$\mathrm{sp} /$ fintech/Pages/default.aspx

Bohang, Fatimah kartini. (2018).Berapa Jumlah Pengguna Internet Indonesia, https://tekno.kompas.com/read/2018/02/22/16453177/berapa-jumlah-pengguna-internetindonesia.

Chrismastianto,Imanuel Adhitya Wulanata. (2017). Analisis Swot Implementasi Teknologi Finansial Terhadap Kualitas Layanan Perbankan Di Indonesia, Volume 20 No. 1

Chief Professor, Dr George A Walker. Editor-in-(2018). The FinTech Edition 2018. Published by FinTecHub London, 2018

Davis, K., Maddock, R., \& Foo, M. (2017). Catching up with Indonesia's fintech industry. Law and Financial Markets Review, 11(1), 33-40. DOI:

10.1080/17521440.2017.1336398

https://research.monash.edu/en/publications/catching-up-with-indonesiasfintech industry

Fintech dan Transformasi Industri Keuangan.(2017)

https://www.pwc.com/id/en/media-centre/pwc-in-news/2017/indonesian/fintech-dantransformasi-industri-keuangan.html

https://www.duniafintech.com/perbedaan-p2p-lending-crowdfunding/

https://konsumen.ojk.go.id/minisitedplk/images/upload/201807131451262/Fintech.pdf

Iqbal Kurniawan (2018)

https://id.techinasia.com/startup-fintech-lending-indonesia-2018

Irma Muzdalifa, Inayah Aulia Rahma, Bella Gita Novali. (2018). Peran Fintech Dalam Meningkatkan Keuangan Inklusif Pada UMKM Di Indonesia (Pendekatan Keuangan Syariah), Jurnal Masharif al-Syariah: Jurnal Ekonomi dan Perbankan Syariah/Vol. 3, No. 1

Panggabean, Eni,V (2017). Empat Fungsi Bank Indonesia https://ekbis.sindonews.com/read/1155326/178/ini-empat-fungsi-bank-indonesiafintech-office

Peraturan Otoritas Jasa Keuangan Nomor 77 /POJK.01/2016, Tentang Layanan Pinjam Meminjam Uang Berbasis Teknologi Informasi

Lee Wetherington, (2014) The Innovation Question Navigating the Future of FinTech and Payments, Jack Henry \& Associates, Inc

Nielsen,Christian \& Lund,Morten. (2014). Business Model Design: Innovating and Globalizing $-2^{\text {nd }}$ edition, ISBN 978-87-403-0639-2

OJK.(2017). Kajian Perlindungan Konsumen Sektor Jasa Keuangan: Perlindungan Konsumen Pada Fintech Jakarta. Departemen Perlindungan Konsumen OJK, 2017.

Sebastian Atmodjo

https://finance.detik.com/moneter/d-4192994/ojk-terbitkan-aturan-baru-soal-fintech-iniisinya

Simon Iqbal Fahlevi, Peran Teknologi Finansial Serta Regulasinya di Indonesia https://www.jurnal.id/en/blog/peran-teknologi-finansial-serta-regulasinya-di-indonesia

Yogie Maharesi

http://feb.ub.ac.id/fintech-dan-ancaman-baru-dalam-sistem-perbankan.html 